\title{
PENINGKATAN KEKAKUAN PEGAS DAUN DENGAN CARA QUENCHING
}

\author{
Pramuko Ilmu Purboputro \\ Teknik Mesin Universitas Muhammadiyah Surakarta \\ Jl. A. Yani Tromol Pos I Surakarta \\ Pramuko_ip@ums.ac.id
}

\begin{abstract}
ABSTRAK
Tujuan penelitian ini adalah untuk mengetahui prosentase komposisi kimia, fasa penyusun struktur mikro, kekerasan dan harga impact spesimen raw material maupun hasil perlakuan panas dengan variasi pendinginan dari komponen pegas daun,. Material uji yang digunakan adalah pegas daun L300 dengan pengujian yang dilakukan meliputi uji komposisi kimia, impact, struktur mikro dan kekerasan dengan variasi quenching air garam, quenching air quenching oli dan annealing. Dari hasil uji komposisi kimia pegas daun termasuk baja karbon sedang $(C=0,300 \%)$. Hasil struktur mikro spesimen raw material didapatkan fasa ferit, perlit halus dan bainit, quenching air garam didapatkan fasa martensit halus dan merata, quenching air didapatkan fasa martensit kasar dan endapan karbida pada batas butir, quenching oli didapatkan sedikit fasa martensit dan banyak endapan karbida pada batas butir serta austenit sisa, annealing didapatkan fasa perlit dan ferit. Hasil uji kekerasan di-dapatkan harga kekerasan rata-rata tertinggi pada spesimen quenching air garam sebesar 598,75 VHN. Hasil pengujian impact harga ketangguhan rata-rata tertinggi (paling liat) adalah spesimen annealing sebesar $0,278 \mathrm{~J} / \mathrm{mm}^{2}$.
\end{abstract}

Kata Kunci: pegas daun, raw material, anil, quench (air, air garam, dan oli)

\section{PENDAHULUAN}

Pada saat ini baja merupakan material yang paling banyak digunakan sebagai bahan industri, karena baja mempunyai sifat-sifat fisis dan mekanis yang bervariasi. Pegas daun termasuk ke dalam golongan baja pegas. Baja pegas sebenarnya tidak mempunyai kekerasan tinggi. Baja ini dapat dikeraskan dan ditingkatkan keuletannya dengan beberapa cara, antara lain dilakukan proses perlakuan panas. Proses perlakuan panas (heat treatment) yang dapat membentuk (merubah) sifat baja dari yang mudah patah menjadi lebih kuat dan ulet atau juga dapat merubah sifat baja dari yang lunak menjadi sangat keras dan sebagainya. Proses heat treatment itu sendiri merupakan salah satu bagian dari proses produksi, namun heat treatment ini hendaknya dipandang terpisah dari rangkaian proses produksi. Heat treatment merupakan proses kombinasi antara pemanasan dan pendinginan terhadap logam atau paduan dalam keadaan padat dalam jangka waktu tertentu yang dimaksudkan untuk memperoleh sifat-sifat tertentu pada logam atau paduan. Pembentukan sifat-sifat inilah yang sangat diperlukan untuk memperoleh material bahan industri yang betulbetul sesuai dengan kebutuhan dan fungsinya.

Pada penelitian ini selain material asli (raw material), juga digunakan spesimen untuk proses pemanasan. Pemanasan yang dilakukan 
adalah dengan memanaskan spesimen baja pegas daun ke dalam oven. Temperatur austenitisasinya adalah $950^{\circ} \mathrm{C}$. Pada temperatur tersebut ditahan selama 30 menit, kemudian dilanjutkan mendinginkannya dengan 4 variasi pendinginan cepat (quenching), yaitu : air, air garam, oli dan pendinginan lambat atau dalam dapur itu sendiri (annealing).

Dari penjelasan langkah penelitian tersebut di atas kemudian timbul pertanyaan : apakah yang terjadi pada sifat fisis dan mekanis dari perlakuan panas dan variasi pendinginan tersebut, khususnya dalam peningkatan kekerasan dan ketangguhan pada baja pegas daun?

\section{TINJAUAN PUSTAKA}

Andi Setiyawan (2003), mengadakan penelitian mengenai pengaruh proses quenching terhadap sifat fisis dan mekanis sudu blower dinamo ampere pada mobil diesel didapatkan kesimpulan bahwa lama waktu penahanan (holding time) pada material ini mempengaruhi sifat mekanis material yaitu terhadap nilai kekerasan. Dimana material dasar tanpa perlakuan memiliki kekerasan rata-rata sebesar $664,1 \mathrm{~kg} /$ $\mathrm{mm}^{2}$, material hasil quenching $850^{\circ} \mathrm{C}$ dengan holding time 1 jam sebesar $723,64 \mathrm{~kg} / \mathrm{mm}^{2}$ dan material hasil quenching $850^{\circ} \mathrm{C}$ dengan holding time 2 jam sebesar $730,5 \mathrm{~kg} / \mathrm{mm}^{2}$.

Analisa proses quenching pada stainless steel seri 304 produk di pasaran yang dilakukan oleh Chandra Dewa Utama (2004) menyimpulkan berdasarkan uji kekuatan tarik, didapat harga kekuatan tarik untuk spesimen tanpa perlakuan panas dengan harga 342,67 N/mm² lebih tinggi dibanding dengan heat treatment. Sedangkan setelah perlakuan panas pada suhu $1000^{\circ} \mathrm{C}$ diquenching di es harga kekuatan tarik paling rendah yaitu 305,83 N/mm². Sehingga kekuatan tarik sebelum diheat treatment lebih meningkat / tinggi daripada setelah mengalami perlakuan panas. Pada perbesaran 200x, untuk hasil foto struktur mikro semua spesimen memperlihatkan adanya butiran-butiran hitam (perlit), butiranbutiran putih (ferit) dan ada juga bintik-bintik hitam (chromium). Ukuran butiran-butiran bertambah besar setelah perlakuan panas. Karbida pada spesimen tanpa perlakuan panas terlihat lebih banyak dibanding dengan spesimen dengan perlakuan panas. Spesimen yang mempunyai jumlah karbida lebih banyak, mempunyai harga kekerasan lebih tinggi.

Gatot Budiyanto (2003) melakukan penelitian tentang pengaruh proses quenching dan annealing terhadap struktur mikro dan kekerasan sprocket Toyota Kijang, yang menunjukkan hasil dari data pengujian kekerasan bahwa untuk raw material merupakan material yang mempunyai harga kekerasan paling tinggi dimana pada bagian ujung didapatkan harga kekerasan $203,4 \mathrm{~kg} / \mathrm{mm}^{2}$, pada bagian tengah $177 \mathrm{~kg} / \mathrm{mm}^{2}$, pada bagian induk $159,9 \mathrm{~kg} / \mathrm{mm}^{2}$. Sedangkan setelah mengalami proses quench dan anneal, harga kekerasannya menjadi turun dibandingkan dengan raw material. Berdasarkan pengamatan struktur mikro untuk tanpa dan dengan proses quenching serta annealing didapatkan struktur mikro ferit dan perlit saja, dimana untuk material proses quenching dan annealing didapatkan struktur butir yang lebih besar dari pada raw material sehingga kekerasannya menjadi turun.

Agung Cahyono (2003) dalam penelitian mengenai peningkatan kualitas kekerasan poros propeller dengan perlakuan panas quenching menyimpulkan bahwa pada pengujian impact didapat harga impact rata-rata raw material 1,7995 Joule $/ \mathrm{mm}^{2}$, sedangkan harga impact rata-rata spesimen quench 1,396 Joule/ $\mathrm{mm}^{2}$. Serta dari data pengujian kekuatan tarik dapat diketahui kekuatan tarik rata-rata pada raw material adalah 599,87 N/mm², sedangkan pada spesimen quench harga kekuatan tarik rata-rata adalah 645,9 N/mm².

\section{METODOLOGI PENELITIAN Alur Penelitian} bar 1. 


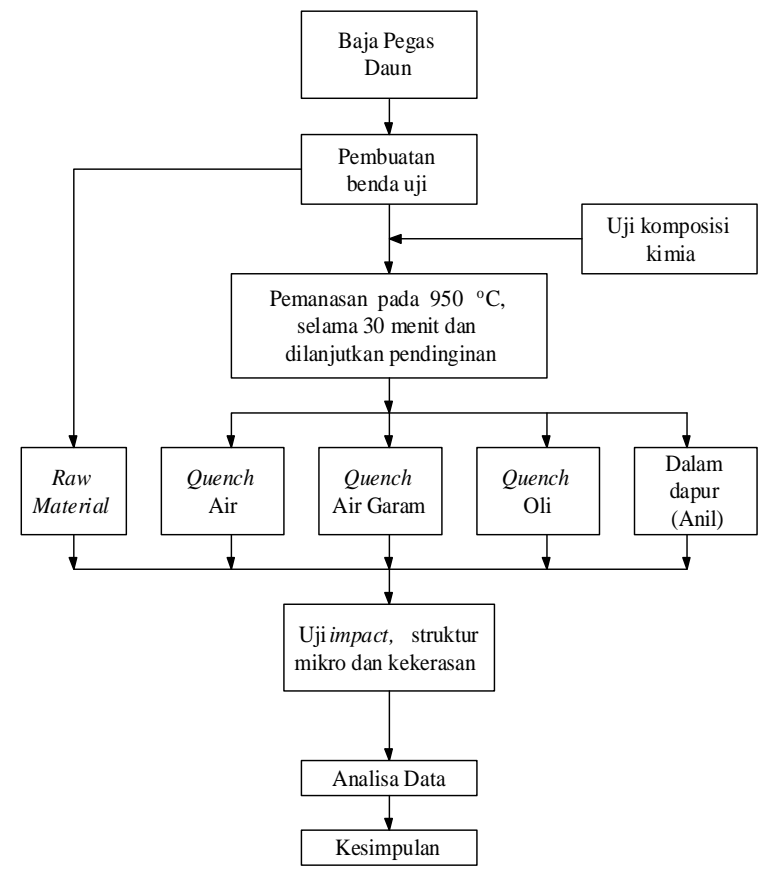

Gambar 1. Alur Penelitian berikut;

Alur Penelitian dapat dijelaskan sebagai

a). Penyiapan Bahan

Bahan yang digunakan dalam penelitian ini adalah baja pegas daun jenis mobil Mitsubitsi berbentuk pelat memanjang.

b). Pembuatan Benda Uji

Pemotongan bahan dengan ketebalan $8 \mathrm{~mm}$, menggunakan gergaji pendinginan dengan air untuk menjaga kestabilan struktur internal agar tidak panas. Adapun benda uji penelitian berjumlah 16 buah, masing-masing 3 buah untuk pengujian impact sekaligus digunakan untuk pengamatan struktur mikro dan kekerasan. Sedangkan benda uji komposisi kimia berjumlah 1 (satu) buah diambil langsung dari raw material.

c). Pengujian Komposisi Kimia

Pengujian ini dilakukan untuk memeriksa dan mengetahui jumlah (prosentase) kandungan unsur paduan yang terdapat pada spesimen, terutama kadar unsur karbon (C).

d). Perlakuan Panas

Perlakuan panas dengan menggunakan dapur pemanas (furnace), pada temperatur pemanasan $950^{\circ} \mathrm{C}$ dan waktu tahan 30 menit.

Alat-alat dan bahan yang digunakan antara dapur pemanas (furnacesedangkan media pencelup : air tawar suhu ruang, Garam $\mathrm{NaCl}$ dan Oli

e). Pengujian Impact

Pengujian ini bertujuan untuk mengetahui keuletan dan ketahanan benda uji terhadap beban dinamis. Uji impact digunakan metode Charpy

f). Pengamatan Struktur Mikro

Pengamatan dilakukan di bawah mikroskop Olympus Metallurgical Microscope dengan pembesaran 200x dan 500x, sedangkan untuk pemotretan dilakukan dengan tambahan alat Olympus Photomicrographic System.

g). Pengujian Kekerasan

Pengujian kekerasan pada penelitian ini adalah menggunakan uji kekerasan Macro Hardness Vickers. Alat yang digunakan adalah Macro Vickers Hardness Tester. Indentor (penetrator) yang digunakan berupa piramida intan dengan bermacam-macam diameter. Diagonal-diagonal piramid yang digunakan adalah $\mathrm{d}_{1}(\mathrm{~mm})$ dan $\mathrm{d}_{2}(\mathrm{~mm})$. Sedangkan beban penekanan yaitu $40 \mathrm{~kg}$ dengan waktu pembebanan selama \pm 5 detik.

\section{HASIL DAN PEMBAHASAN \\ Pengujian Komposisi Kimia}

Hasil pengujian Komposisi kimia dapat dilihat pada tabel 1

Tabel 1. Hasil pengujian Komposisi kimia

\begin{tabular}{|c|c|}
\hline Unsur Kimia & $\begin{array}{c}\text { Prosentase Unsur } \\
\mathbf{( \% )}\end{array}$ \\
\hline $\mathbf{F e}$ & 97,07 \\
\hline $\mathbf{S i}$ & 1,292 \\
\hline $\mathbf{M n}$ & 0,735 \\
\hline $\mathbf{W}$ & 0,040 \\
\hline $\mathbf{C}$ & 0,300 \\
\hline $\mathbf{C r}$ & 0,220 \\
\hline $\mathbf{N i}$ & 0,152 \\
\hline $\mathbf{C u}$ & 0,122 \\
\hline $\mathbf{M o}$ & 0,031 \\
\hline $\mathbf{S}$ & 0,013 \\
\hline $\mathbf{N b}$ & 0,010 \\
\hline $\mathbf{P}$ & 0,004 \\
\hline $\mathbf{V}$ & 0,000 \\
\hline $\mathbf{A l}$ & 0,000 \\
\hline $\mathbf{T i}$ & 0,000 \\
\hline
\end{tabular}


Dengan melihat data hasil pengujian komposisi kimia didapatkan 15 unsur. Pada spesimen spare part pegas daun mengandung 0,300 \% C sehingga berdasarkan unsur karbon diklasifikasikan sebagai baja karbon sedang. Unsur penyusun utama selain besi $(\mathrm{Fe})=97,07$ $\%$ juga didapatkan unsur silikon $(\mathrm{Si})=1,292 \%$ yang berpengaruh dalam meningkatkan kekuatan, kekerasan, kemampuan diperkeras secara keseluruhan, tahan aus, ketahanan terhadap panas dan karat, tetapi juga mampu menurunkan tegangan, kemampuan tempa dan meningkatkan kemampuan las. Mangan $(\mathrm{Mn})=$ 0,735 \% berguna untuk meningkatkan kekerasan, kekuatan dan mampu diperkeras pada baja.

Unsur tambahan dalam jumlah yang relatif kecil, yaitu : wolfram $(\mathrm{W})=0,04 \%$; molibden $(\mathrm{Mo})=0,031 \%$; sulphur $(\mathrm{S})=0,013 \%$, niobium $(\mathrm{Nb})=0,01 \%$; phospor $(\mathrm{P})=0,004$ $\%$; vanadium $(\mathrm{V})=0,000 \%$; aluminium $(\mathrm{Al})=$ $0,000 \%$ dan titanium $(\mathrm{Ti})=0,000 \%$.

\section{Pengamatan Struktur Mikro}

Hasil foto mikro dapat dilihat pada gambar 2 sampai 5 .

Dari hasil pengamatan struktur mikro raw material (gambar 2) menunjukkan fasa yang tampak adalah bainit. Bainit tersusun atas ferit (warna putih) yang berbentuk bilah (lath) dan sementit $\left(\mathrm{Fe}_{3} \mathrm{C}\right)$ yang mengendap pada batas butir. Kekerasan fasa bainit masih di bawah martensit. Struktur bainit mirip jarum-jarum pendek / butiran beras, sedikit mirip dengan martensit akan tetapi lebih liat dari martensit dan lebih keras dari perlit. Sedikit didapatkan ferit, perlit halus (warna hitam) dan dominasi pada bainit. Proses terbentuknya bainit karena adanya proses austemper pada pembuatan produk sebelumnya.

Gambar 3 Struktur mikro quenching air garam menunjukkan adanya fasa martensit yang dapat menunjukkan telah terjadinya pendinginan yang sangat cepat (quench). Pada quenching air garam, martensit yang terbentuk lebih rapat dan merata. Laju dingin cepat menghasilkan ukuran dan struktur butir yang halus. Selama pemanasan mendekati temperatur austenitisasi sudah terjadi kelarutan karbida ke dalam austenit. Transformasi selesai pada temperatur $\mathrm{M}_{\mathrm{f}}$. Hampir seluruhnya menjadi martensit.

Pada foto Struktur mikro quenching air (gambar 4) didapatkan fasa martensit yang orientasi atau penyebarannya tidak merata dan tidak tersusun rapat (meregang). Juga tampak kondisi batas butir yang berukuran besar yang menunjukkan pertumbuhan butir yang cukup banyak. Terjadi pengendapan karbida (carbide precipitation) pada batas butir dan tidak ikut dalam reaksi pembentukan martensit, sehingga martensit yang dihasilkan sedikit.

Struktur mikro quenching oli ditunjukkan pada gambar 5. Tampak batas butir bertumbuh semakin besar dan martensit dalam bentuk jarum-jarum berukuran besar, menunjukkan pertumbuhan butir yang cukup banyak. Karena suhu akibat pemanasan tidak cepat turun mengakibatkan masih didapatkan karbida mengendap pada batas butir yang menunjukkan belum seluruh karbon larut dalam austenit.

Gambar 6 menunjukan Struktur mikro annealing. Dari hasil anil tampak foto mikro adanya fasa ferit dan perlit. Ferit tampak berwarna putih dan bersifat lunak. Sedangkan perlit berwarna gelap merupakan campuran antara ferit dan sementit $\left(\mathrm{Fe}_{3} \mathrm{C}\right)$ yang bersifat keras dan liat. Fasa didominasi ferit sehingga sifat keliatan sangat mendominasi. Struktur kristal yang terjadi bentuknya bulat-bulat sehingga sifatnya lunak serta ikatannya lemah

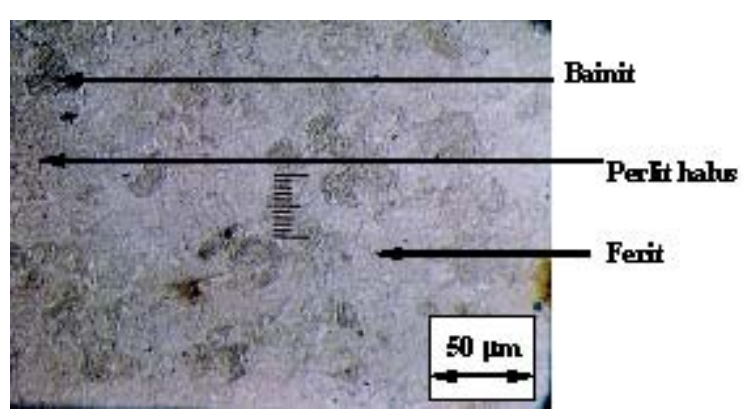

Gambar 2. Struktur Mikro Spesimen Raw Material pada Perbesaran 200x 


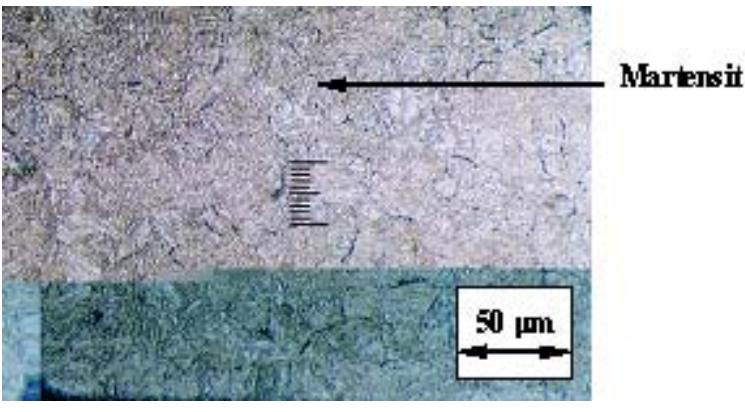

Gambar 3. Struktur Mikro Spesimen Quench Air Garam pada Perbesaran 200x

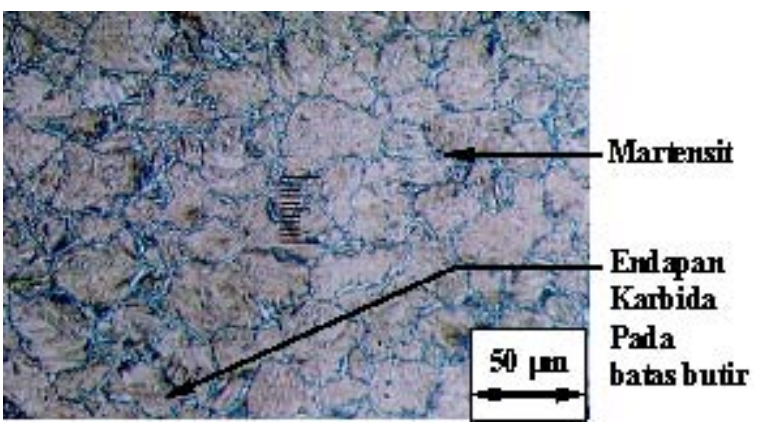

Gambar 4. Struktur Mikro Spesimen Quench Air pada Perbesaran 200x

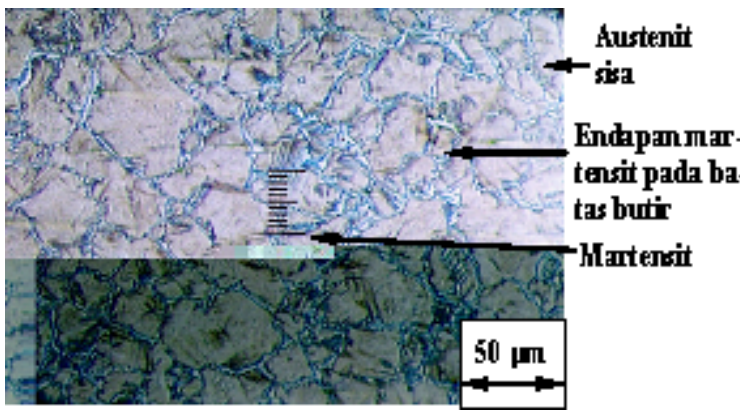

Gambar 5. Struktur Mikro Spesimen Quench Oli pada Perbesaran 200x

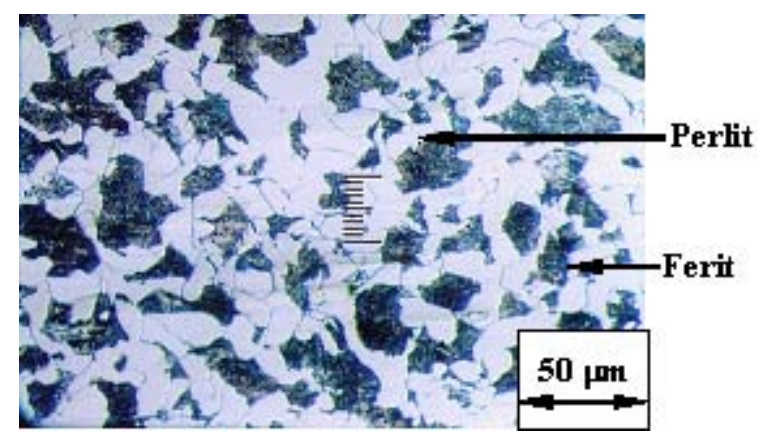

Gambar 6. Struktur Mikro Spesimen Anil pada Perbesaran 200x

\section{Hasil Pengujian Kekerasan}

Histogram hasil pengujian kekerasan dapat dilihat pada gambar 7. Dari hasil pengujian kekerasan didapatkan harga kekerasan rata-rata tertinggi pada spesimen quenching air garam sebesar 598,75 VHN dan berturut-turut menuju posisi terendah yaitu : spesimen quenching air sebesar 592,98 VHN, spesimen quenching oli sebesar 569,63 VHN, spesimen raw material sebesar 409,31 VHN dan paling rendah spesimen annealing sebesar 222,176 VHN.

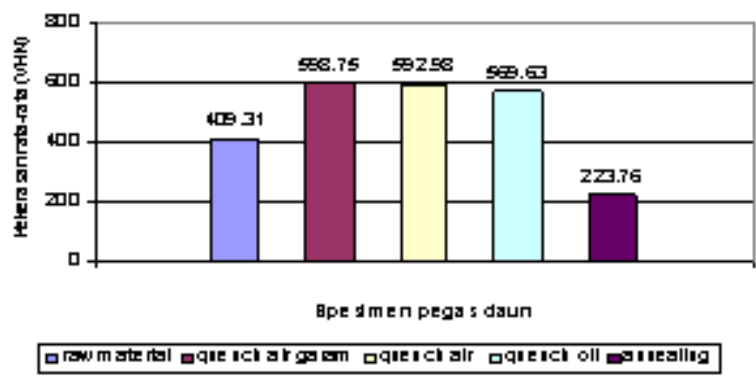

Gambar 7. Histogram Harga Kekerasan Rata-rata

Spesimen quenching air garam memiliki harga kekerasan rata-rata tertinggi sebesar karena laju panas paling rendah atau dengan pendinginan paling cepat. Dengan penambahan garam dapur $10 \%$ efektif untuk mengurangi hambatan thermal (lapisan uap) yang terbentuk ketika pencelupan benda uji dalam keadaan panas ke air. Sehingga transformasi fasa dapat berjalan cepat sekali menuju terbentuknya fasa martensit secara penuh dan dibuktikan dengan tercapainya harga kekerasan paling tinggi. Harga kekerasan rata-rata spesimen quenching air di ᄂ awah spesimen quenching air garam, hal ini isebabkan pada quenching air terdapat ambatan panas untuk lepas ke air ketika proses slup. Pada saat pertama kali terjadi kontak tara benda dengan air akan terjadi pendinginan spat hanya sesaat, karena akan segera terentuk uap air yang menempel dipermukaan enda (vapour blanket stage), yang mengalangi perpindahan panas dari benda ke air. Kekerasan rata-rata spesimen quenching oli lebih rendah daripada quenching air, karena 
pendinginan oli (minyak) lebih lambat daripada air. Hal ini disebabkan pada waktu pencelupan timbul gelembung udara yang terperangkap dalam minyak sehingga mengganggu pengaliran panas dari benda kerja ke minyak. Adanya gelembung udara yang menempel di permukaan benda kerja akan mengakibatkan kekerasan lebih rendah daripada quenching air. Harga kekerasan rata-rata paling rendah pada spesimen annealing. Hal ini disebabkan penggunaan pendingin udara yang diam (dalam dapur/penyekat thermal) dimana mempunyai kapasitas pendinginan yang rendah. Dengan laju pendinginan yang rendah maka didapati keuntungan yang lebih daripada quenching yaitu akibat thermal stress dapat diperkecil sehingga benda uji dapat terbebas dari retak/distors.

\section{Pengujian Impact}

Histogram hasil pengujian impact dapat dilihat pada gambar $\mathbf{8}$.

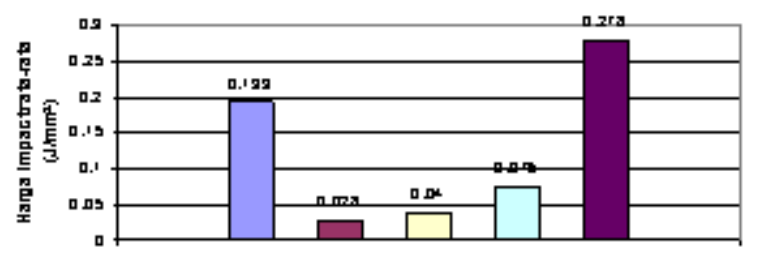

צFueniun Fugux duun

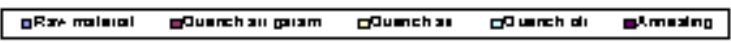

Gambar 8. Histogram Perbandingan Harga Impact Rata-rata

Dari hasil pengujian impact didapatkan harga ketangguhan rata-rata tertinggi (paling liat) pada spesimen annealing sebesar $0,278 \mathrm{~J} / \mathrm{mm}^{2}$ dan berturut-turut menuju posisi terendah yaitu : spesimen raw material sebesar $0,193 \mathrm{~J} / \mathrm{mm}^{2}$, spesimen quenching oli sebesar $0,075 \mathrm{~J} / \mathrm{mm}^{2}$, spesimen quenching air sebesar $0,04 \mathrm{~J} / \mathrm{mm}^{2}$ dan terendah (paling getas) spesimen quenching air garam sebesar $0,028 \mathrm{~J} / \mathrm{mm}^{2}$. Spesimen annealing merupakan spesimen yang paling liat hal ini disebabkan pendinginan dengan laju yang paling lambat akan membentuk butiran kristal logam bulat-bulat dengan jarak yang berjauhan sehingga ikatan antar butir lemah dan memudahkan terjadinya pergeseran (dislokasi) atau cacat garis. Disisi lain, spesimen quenching air garam merupakan spesimen yang paling getas dengan harga impact rata-rata terendah $\left(0,028 \mathrm{~J} / \mathrm{mm}^{2}\right)$. Hal ini disebabkan adanya pendinginan cepat (kondisi laju panas rendah) maka tidak ada energi thermal yang memungkinkan atom-atom logam untuk melompat.

Pada pengujian impact ini juga dianalisa bentuk permukaan penampang patahan. Dari foto-foto tersebut tampak bahwa permukaan penampang patahan spesimen annealing memiliki permukaan patahan yang berbentuk runcing atau tidak rata dan mengkilat, jika potongan disambungkan terdapat banyak deformasi bahan. Hal ini menunjukkan bahwa patahan masih lebih ulet daripada spesimen raw material, quenching air, quenching air garam dan quenching oli. Pada spesimen quench air garam merupakan patah getas (keliatan rendah) permukaan patahan lebih nampak rata (buram) serta didapatkan sedikit sekali runcing. Pada spesimen quenching air garam memiliki pola patahan dengan butiran tampak halus yang menunjukkan sifat kekerasannya yang tinggi.

\section{KESIMPULAN}

Berdasarkan data penelitian dan analisa dapat ditarik kesimpulan sebagai berikut :

1. Dari hasil pengujian komposisi kimia pegas daun termasuk baja karbon sedang $(\mathrm{C}=$ $0,300 \%$ ) dengan unsur penyusun utama adalah besi $(\mathrm{Fe})=97,07 \%$; silikon $(\mathrm{Si})=$ $1,292 \%$ dan mangan $(\mathrm{Mn})=0,735 \%$.

2. Dari hasil pengamatan struktur mikro spesimen raw material didapatkan fasa ferit, perlit halus dan bainit, quenching air garam didapatkan fasa martensit halus dan merata, quenching air didapatkan fasa martensit kasar dan endapan karbida pada batas butir, quenching oli didapatkan sedikit fasa martensit dan banyak endapan karbida pada batas butir serta austenit sisa, annealing didapatkan fasa perlit dan ferit.

3. Dari hasil pengujian kekerasan didapatkan harga kekerasan rata-rata tertinggi pada spesimen quenching air garam sebesar 598,75 
VHN dan berturut-turut menuju posisi terendah yaitu : spesimen quenching air sebesar $592,98 \mathrm{VHN}$, spesimen quenching oli sebesar 569,63 VHN, spesimen raw material sebesar 409,31 VHN dan paling rendah spesimen annealing sebesar 222,176 VHN.

4. Dari hasil pengujian impact didapatkan harga ketangguhan rata-rata tertinggi (paling liat) adalah spesimen annealing sebesar $0,278 \mathrm{~J} / \mathrm{mm}^{2}$ dan berturut-turut menuju posisi terendah yaitu : spesimen raw material sebesar $0,193 \mathrm{~J} / \mathrm{mm}^{2}$, spesimen quenching oli sebesar $0,075 \mathrm{~J} / \mathrm{mm}^{2}$, spesimen quenching air sebesar $0,04 \mathrm{~J} / \mathrm{mm}^{2}$ dan terendah (paling getas) adalah spesimen quenching air garam sebesar $0,028 \mathrm{~J} / \mathrm{mm}^{2}$.

\section{DAFTAR PUSTAKA}

Budiyanto, G., 2003, Tugas Akhir : Pengaruh proses quenching dan annealing terhadap struktur mikro dan kekerasan sprocket Toyota Kijang, Universitas Muhammadiyah Surakarta

Cahyono, A., 2003, Tugas Akhir : Penelitian Mengenai Peningkatan Kualitas Kekerasan Poros Propeller dengan Perlakuan Panas Quenching, Universitas Muhammadiyah Surakarta

Dewa Utama, C., 2004, Tugas Akhir : Proses Quenching pada Stainless Steel Seri 304 Produk di Pasaran, Universitas Muhammadiyah Surakarta

Setiyawan, A., 2003, Tugas Akhir : Penelitian Mengenai Pengaruh Proses Quenching Terhadap Sifat Fisis dan Mekanis Sudu Blower Dinamo Ampere pada Mobil Diesel, Universitas Muhammadiyah Surakarta

Surdia, T.; Saito, S., 1999, Pengetahuan Bahan Teknik, Cetakan ke-4, PT. Pradnya Paramita, Jakarta 